\title{
Presyncopal Cardiac Contractility and Autonomic Activity in Young Healthy Males
}

\author{
E. K. GRASSER ${ }^{1}$, N. GOSWAMI ${ }^{1}$, H. HINGHOFER-SZALKAY $Y^{1,2}$ \\ ${ }^{1}$ Institute of Physiology, Center of Physiological Medicine, Medical University Graz, ${ }^{2}$ Institute of \\ Adaptive and Spaceflight Physiology, Graz, Austria
}

Received May 2, 2008

Accepted October 15, 2008

On-line December 17, 2008

\begin{abstract}
Summary
We investigated non-invasively cardiac contractility and autonomic nervous activity during presyncopal orthostatic stress induced in healthy humans. A graded orthostatic stress (GOS) paradigm, consisting of head-up tilt (HUT) combined with lower body negative pressure (LBNP) of increasing magnitude, was used to reach a presyncopal end-point in 15 healthy adults. Continuous beat-to-beat hemodynamic and autonomic parameters were recorded. From supine control (C1) to presyncope (PS), total peripheral resistance index (TPRI) decreased from $2300 \pm 500$ to $1910 \pm 320$ dyne*s*m²/cm^5 $(p=0.004)$, index of contractility (IC) from $59 \pm 14$ to $27 \pm 61000 / \mathrm{s}$ $(p<0.0001)$, left ventricular working index (LVWI) from $5.2 \pm 1.3$ vs. $3.6 \pm 0.6 \mathrm{mmHg} * \mathrm{~L} /\left(\min ^{*} \mathrm{~m}^{2}\right)(p=0.0001)$ and acceleration index (ACI) from $65 \pm 18$ vs. $54 \pm 15100 / \mathrm{s}^{2} \quad(p=0.04)$. Low frequency variation of diastolic blood pressure $\left(L F_{n u} d B P\right)$ increased from $51 \pm 14$ to $67 \pm 11 \%(p=0.0006)$ and of systolic blood pressure $\left(L_{n u} S B P\right)$ from $50 \pm 6$ vs. $67 \pm 8 \%(p<0.0001)$. High frequency variation of $\mathrm{RR}$-interval $\left(\mathrm{HF}_{\mathrm{ms}} \mathrm{RRI}\right)$ decreased from $385 \pm 320$ to $38 \pm 43 \mathrm{~ms}^{2}(p=0.001)$. From late GOS (G3) to PS, TPRI decreased from $2540 \pm 640$ to $1910 \pm 320$ dyne*s*m²/cm^5 $(p=0.003)$, IC from $35 \pm 6$ to $27 \pm 61000 / s$ $(p=0.003)$, LVWI from $4.6 \pm 0.9$ to $3.6 \pm 0.6 \mathrm{mmHg} * \mathrm{~L} /\left(\mathrm{min} / \mathrm{m}^{2}\right)$ $(p=0.003), L F_{n u} S B P$ from $71 \pm 8$ to $67 \pm 8 \%(p=0.03), L F_{m m H g^{2}} d B P$ from $6.6 \pm 4.0$ to $4.8 \pm 2.9 \mathrm{mmHg}^{2}(p=0.0001), \mathrm{LF}_{\mathrm{mmHg}^{2}} \mathrm{SBP}$ from $9.7 \pm 7.8$ to $7.4 \pm 4.8 \mathrm{mmHg}^{2}(p=0.01)$. $\mathrm{HF}_{\text {nuRRI }}$ increased from $19 \pm 8$ to $28 \pm 13 \%(p=0.008)$. Myocardial contractility indices and parameters of sympathetic activity were reduced in the presyncopal state, while parasympathic activity was increased. This suggests a decrease in cardiac contractility during orthostatically induced presyncope in healthy subjects.
\end{abstract}

\section{Key words}

Hemodynamics - Total peripheral resistance • Blood pressure • Impedance cardiography • Sympathetic withdrawal • LBNP • HUT

\section{Corresponding author}

N. Goswami, Institute of Physiology, Center of Physiological Medicine, Medical University Graz, Harrachgasse 21/5, 8010 Graz, Austria. Fax: +43 316380 9630. E-mail: nandu.goswami@medunigraz.at

\section{Introduction}

Presyncope is a state immediately preceding a syncopal event, defined as a sudden, brief, transient loss of consciousness, with a loss of postural tone (Kapoor 2000). 'Physiological' syncope within the frame of an orthostatic stress paradigm develops as a result of critically diminished cardiac preload due to low venous return. Once brain perfusion is reduced below a critical level, a "neurocardiogenic" reflex ("vasovagal attack") is triggered that causes vasodilation, reduces heart rate, cardiac output, and consequently blood pressure, and loss of consciousness is imminent. Although the trigger for the rapid and sudden switch in autonomic responses still remains elusive and poorly understood, it has frequently been emphasized that the autonomic nervous system plays a key role as a final common pathway leading to syncope (Morillo et al. 1994, Furlan et al. 1998, Mangin et al. 2001).

It is unclear how exactly sympathetic activity changes in a presyncopal situation: power spectral analysis of RR variability indicates increased, unchanged, 
or reduced sympathetic activity immediately preceding a vasovagal event, and microneurography has revealed rather unpredictable patterns (Mosqueda-Garcia et al. 1997). Pagani et al. (1997) have concluded that sympathetic activation is associated with an increase of the LF component of both muscle nerve sympathetic activity (MSNA) and systolic arterial pressure (SAP). They suggested to use the changes in LF of SAP variability as a marker of changes in sympathetic efferent activity. They also found that the HF component of MSNA variability in normalized units was closely related with the HF component (in normalized units) of RRI (Pagani et al. 1997).

Vaso-vagal syncope might be triggered by a stimulation of cardiac receptors, and inadequate stimulation of mechanoreceptors may be caused by excessive myocardial contractility (Oberg and Thoren 1972). While some found powerful presyncopal myocardial activity (Shalev et al. 1991), others observed no difference (Bellard et al. 2003) or even decreased myocardial contractility (Liu et al. 2000). Peak endocardial acceleration (PEA) measurements provided the indication for decreased myocardial contractility during fainting (Mangin et al. 2001) as did impedance cardiography (Mitro and Hijová 2006). However, these studies were carried out in patients.

Based on the hypothesis of clear indication of decreasing presyncopal myocardial contractility together with a shift away from sympathetic towards parasympathetic activity, the aim of this study was to investigate non-invasively indices of cardiac contractility, autonomic nervous activity, and hemodynamics during and after presyncopal orthostatic stress in healthy humans.

\section{Materials and Methods}

\section{Subjects}

To avoid effects of confounding variables such as height, gender or athletic training on orthostatic tolerance (Goswami et al. 2008) we selected fifteen healthy males $(31 \pm 2$ years, $75 \pm 3 \mathrm{~kg}, 182 \pm 2 \mathrm{~cm}$, BMI $23 \pm 1 \mathrm{~kg} / \mathrm{m}^{2}$ ) with no history of syncope, pathological condition (neurological, cardiovascular, endocrine) and not on any medication. Test subjects abstained from alcohol, smoking and caffeine as well as from vigorous exercise for $48 \mathrm{~h}$ prior to examination, and were advised not to change their fluid and salt intake as governed by their usual dietary habits. A light breakfast with sufficient fluid intake was allowed before the test. All studies occurred between 09:00 and 12:00 $\mathrm{h}$ in an airconditioned, semi-dark room (temperature $22 \pm 1{ }^{\circ} \mathrm{C}$, humidity $55 \%$ ). The Graz Medical University's Ethics Committee approved the study, and written informed consent was obtained from each subject.

\section{Experimental protocol}

We used the Adaptive and Spaceflight Physiology Institute's multi-stimulation test device (www.meduni-graz.at/iap/AHST.htm) that allows for $<10 \mathrm{~s}$ postural changes and LBNP build-up (Fig. 1, below). The sealing was maintained at the iliac crest, as sealing position has been shown to affect hemodynamic responses (Goswami et al. 2009). Test subjects were secured and had access to an emergency shutdown (automatic return to supine and pressure neutralization) at all times. The experiment commenced with $5 \mathrm{~min} 70^{\circ}$ passive head-up tilt (HUT). It was followed by graded LBNP, which started with $20 \mathrm{mmHg}$ suction, and was increased by $10 \mathrm{mmHg}$ each in 3-min intervals, until presyncope occurred. The criteria of presyncope were a) blood pressure drop below systolic $80 \mathrm{mmHg}$ or by $\geq 25$ $\mathrm{mmHg} / \mathrm{min}$, diastolic by $\geq 15 \mathrm{mmHg} / \mathrm{min}$, and/or heart rate decrease by $\geq 15$ bpm, and b) lightheadedness, dizziness, visual disturbances, nausea, stomach awareness, clammy skin, excessive sweating, or skin pallor (Hinghofer-Szalkay et al. 2006).

\section{Hemodynamics}

Blood pressure was monitored using the Penaz principle (Wesseling 1996). Total peripheral resistance index (TPRI) was calculated as mean arterial blood pressure/cardiac index and mean arterial blood pressure as calculated from diastolic and systolic pressures, respectively: $\mathrm{MAP}=\mathrm{dBP}+1 / 3(\mathrm{sBP}-\mathrm{dBP})$. Cardiac index $(\mathrm{CI})$, which relates heart performance to the size of the individual, was calculated as cardiac output/body surface area. Stroke index was calculated as stroke volume/body surface area. Impedance cardiography, in which the changes in thoracic impedance are converted to reflect changes in thoracic fluid/volume over time, was performed based on the original Kubicek approach but using an improved estimate of thoracic volume (Task Force Monitor, TFM ()$_{)}$.

ECG/impedance electrodes were positioned together with upper arm and finger blood pressure cuffs (Fortin et al. 2006). Electrode strips were placed at the neck and thoracic regions, the latter specifically at the 
midclavicular line at the xiphoid process level. The method has been described in detail elsewhere (Fortin et al. 2006). Recorded and calculated data were stored realtime beat-to-beat throughout the entire experiment.

\section{Heart rate and blood pressure variability}

Low (LF: 0.05-0.17 Hz) and high frequency (HF: $0.17-0.40 \mathrm{~Hz}$ ) power components of RR-intervals (RR), diastolic blood pressure (dBP) and systolic blood pressure (sBP) were evaluated and given in absolute values $\left(\mathrm{ms}^{2}\right)$ and normalized units (nu) applying an autoregressive method, as normalization minimizes disruptive effects of changes in total power (Camm et al. 1996). The referring frequency bands indicate autonomic modulation of the sinoatrial node and of vasomotion (Camm et al. 1996). In the present study we used changes in the LF range of arterial blood pressure to assess information about sympathetic activity, as it is generally considered to be associated with sympathetic nerve activity (Malliani et al. 1991, Pagani et al. 1997). We used changes in the HF range of heart rate variability (HF_RRI) to assess parasympathic activity because HF_RRI is primarily mediated by parasympathetic nerve modulation, whereas LF_RRI is probably affected by both parasympathetic and sympathetic modulations (Pagani et al. 1997, Stauss 2003).

\section{Myocardial contractility parameters}

Myocardial contractility parameters were derived through impedance cardiography measurement. The index of contractility (IC) reflects the aortic peak flow and it is the maximum impedance changes $\left(\Delta \mathrm{Z} / \Delta \mathrm{t}_{\max }\right)$ normalized to the ground impedance $\mathrm{Z}_{0}$. The acceleration index (ACI) refers to the maximum aortic blood acceleration as a function of time and is defined as $\Delta^{2} \mathrm{Z} / \Delta \mathrm{t}_{\text {max }}^{2}$. The left ventricular work index (LVWI) was calculated as (mean blood pressure - pulmonary capillary occlusion pressure (fixed to $7 \mathrm{mmHg}$ ) $*$ cardiac index * const.

\section{Data acquisition and analysis}

Data from distinct protocol time points were used to obtain the defined parameter patterns, particularly from the period preceding and immediately after presyncope. In each test, the following protocol points were identified: Supine control (C1), early tilt (G1), late tilt (G2), late graded orthostatic stress [GOS] (G3), presyncope (PS), early recovery (PG1) and late control (PG2). All data are means from observation periods: $\mathrm{C} 1$, $60 \mathrm{~s}$ before GOS; G1, the immediate $60 \mathrm{~s}$ after commencing HUT; G2, the last 60 s of HUT; G3, the last minute of LBNP 20 (this was the only LBNP step finished by all test subjects); PS, the last minute of GOS preceding presyncope; PG1, the first sixty seconds after GOS; and PG2, the last $60 \mathrm{~s}$ before termination of the experiment, which was $15 \mathrm{~min}$ after return to supine.

\section{Statistical analysis}

Variables were tested for normality using the D'Agostino \& Pearson omnibus normality test and expressed as mean value \pm S.D. Repeated measures ANOVA with Dunnett post-hoc or the Friedman test with Dunn post-hoc testing were used to test for changes in all tested variables and parameters with orthostatic loading (C1 compared to all other time periods). All reported $\mathrm{p}$ values are two-sided. For all tests, significance was set at $\mathrm{p} \leq 0.05$. All analyses were performed using GraphPad Prism 5 software.

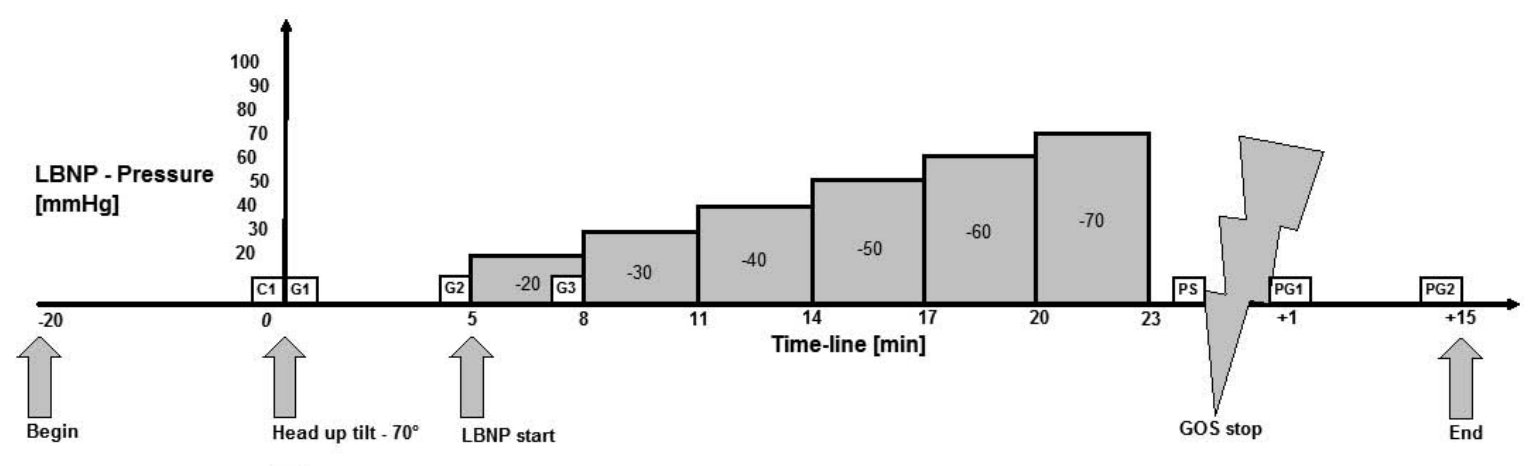

time frames for statistical analysis ( 60 seconds)

Fig. 1. Experimental protocol and details of specific points at which the data were analyzed. C1: supine control; G1: early tilt; G2: late tilt; G3: late GOS; PS: presyncope; PG1: early recovery; PG2: late control. 
IC

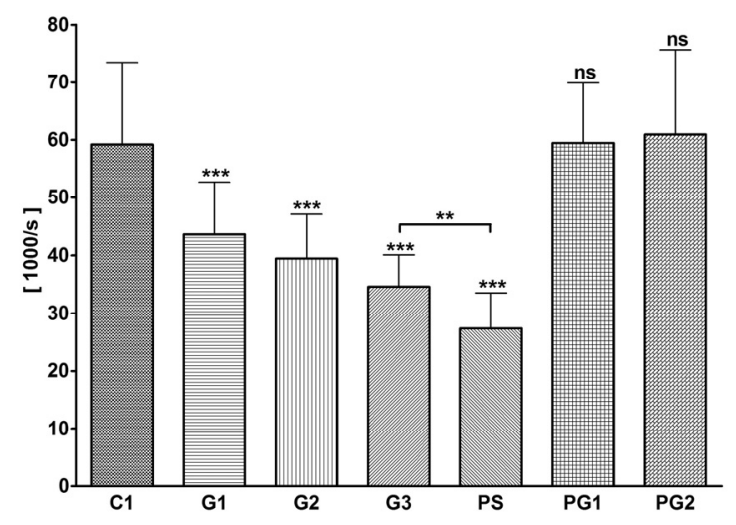

$\mathrm{ACl}$

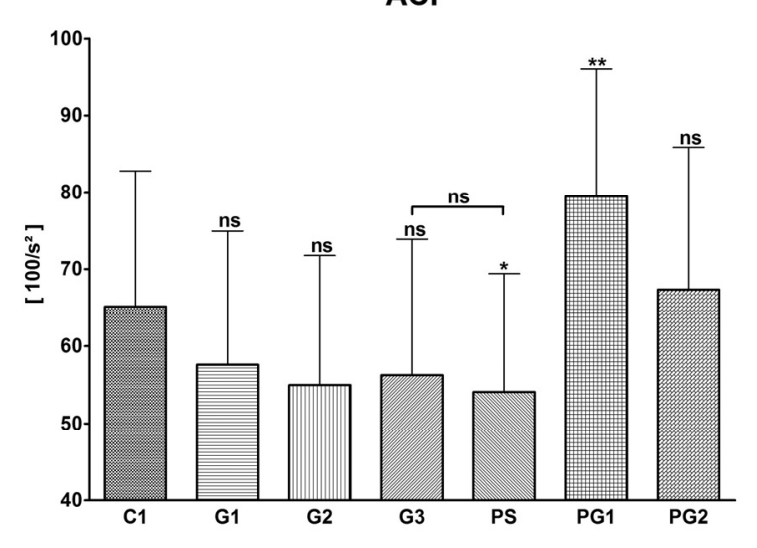

LVWI

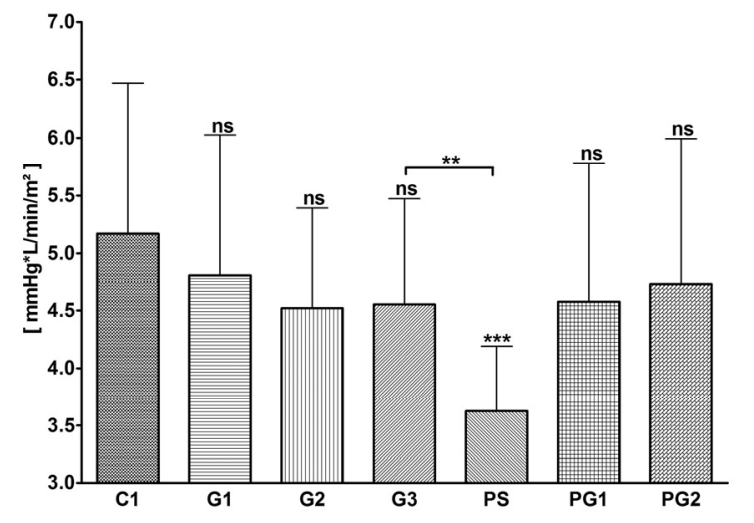

Fig. 2. Changes in myocardial contractility parameters during and after GOS. IC: index of contractility, ACI: acceleration index, LVWI: left ventricular working index. C1: supine control; $\mathrm{G} 1$ : early tilt; G2: late tilt; G3: late GOS; PS: presyncope; PG1: early recovery; PG2: late control. Bars show means \pm S.D. ***, $\mathrm{P}<0.0005 ; * *, \mathrm{P}<0.005 ; *, \mathrm{P}<0.05$.

\section{Results}

Mean orthostatic tolerance time was $13 \pm 1 \mathrm{~min}$. Six test subjects showed a pure vasodepressor reaction prior to presyncope, five a mixed (cardioinhibitory and vasodepressor) reaction and four showed symptoms like lightheadedness, sweating, nausea, and visual disturbances.

\section{Hemodynamic changes during and after GOS}

Compared to supine control (C1) SI, CI, TPRI and blood pressure values were reduced and HR and TI increased in presyncopal state (PS) (Table 1). After GOS, $\mathrm{HR}, \mathrm{SI}$, and CI quickly returned to normal (not different from $\mathrm{C} 1$ ), while mean arterial blood pressure and TPRI was below $\mathrm{C} 1$ levels at PG1, and TI remained elevated at PG1 and PG2 (Table 1). In comparing late GOS (G3) with PS, diminished TPRI was observed (Table 1).

\section{Changes in myocardial contractility parameters during and after GOS}

Fig. 2 shows the myocardial contractility indices IC, ACI, LVWI at defined protocol times. IC decreased stepwise during GOS $(59 \pm 14$ to $27 \pm 61000 / \mathrm{s} ; \mathrm{p}<0.0001)$. ACI was significantly decreased ( $65 \pm 18$ to $54 \pm 15100 / \mathrm{s}^{2}$; $\mathrm{p}=0.04$ ) only at PS, and increased above $\mathrm{Cl}$ at PG1 ( $65 \pm 18$ to $80 \pm 17100 / \mathrm{s}^{2} ; \mathrm{p}=0.002$ ). Similarly, LVWI was reduced at PS $\left(5.2 \pm 1.3\right.$ to $3.6 \pm 0.6 \mathrm{mmHg} * \mathrm{~L} / \mathrm{min} / \mathrm{m}^{2}$; $\mathrm{p}<0.0001$ ) (Fig 1). In late GOS (G3), as compared with PS, IC (35 46 to $27 \pm 61000 / \mathrm{s} ; \mathrm{p}=0.003$ ) and LVWI (4.6 \pm 0.9 to $3.6 \pm 0.6 \mathrm{mmHg} * \mathrm{~L} /\left(\mathrm{min}^{*} \mathrm{~m}^{2}\right) ; \mathrm{p}=0.003$ ) were decreased, whereas ACI was unchanged (Fig. 2).

\section{Autonomic changes during and after GOS}

$\mathrm{LF}_{\mathrm{nu}} \mathrm{dBP}$ and $\mathrm{LF}_{\mathrm{nu}} \mathrm{sBP}$ increased in a stepwise fashion with a peak at G3 $(51 \pm 4$ to $70 \pm 15 \%$; $<<0.0001$ and $50 \pm 6$ to $71 \pm 8 \% ; \mathrm{p}<0.0001$, respectively) and returned to supine rest values after GOS (Fig. 3). Even at presyncope (PS), both $\mathrm{LF}_{\text {nu }} \mathrm{dBP}(51 \pm 14$ to $67 \pm 11 \%$; $\mathrm{p}=0.0006)$ and $\mathrm{LF}_{\mathrm{nu}} \mathrm{sBP}(50 \pm 6$ to $67 \pm 8 \% ; \mathrm{p}<0.0001)$ increased compared to supine control. Compared late GOS (G3) with presyncope (PS) $L_{\mathrm{nu}} \mathrm{sBP}$ fell from $71 \pm 8$ to $67 \pm 8 \%(\mathrm{p}=0.03)$. There was a presyncopal decrease during G3, in particular $\mathrm{LF}_{\mathrm{mmHg}} \mathrm{dBP}^{2}$ fell from $6.6 \pm 4.0$ to $4.8 \pm 2.9 \mathrm{mmHg}^{2} \quad(\mathrm{p}=0.0001)$ and $\mathrm{LF}_{\mathrm{mmHg}} \mathrm{SBP}$ from $9.7 \pm 7.8$ to $7.4 \pm 4.8 \mathrm{mmHg}^{2}$ ( $\mathrm{p}=0.01$ ) (Fig. 3 ).

$\mathrm{HF}_{\mathrm{nu}} \mathrm{RRI}$ decreased significantly at $\mathrm{G} 2(35 \pm 15$ to $17 \pm 7 \% ; \mathrm{p}=0.0002)$ and $\mathrm{G} 3(35 \pm 15$ to $18 \pm 8 \% ; \mathrm{p}=0.003)$ compared to supine control (C1) and increased from G3 ( $19 \pm 8$ to $28 \pm 13 \%$; $\mathrm{p}=0.01$ ) to presyncopal point (PS) (Fig. 4). During GOS $\mathrm{HF}_{\mathrm{ms}^{2}} \mathrm{RRI}$ decreased in a stepwise fashion ( $385 \pm 320$ to $38 \pm 43 \mathrm{~ms}^{2} ; \mathrm{p}=0.0009$ ) and returned quickly, after cessation of GOS, to C1 levels (Fig. 3). In comparing late GOS (G3) with presyncope (PS), diminished values of $\mathrm{HF}_{\mathrm{ms}}{ }^{2} \mathrm{RRI}$ were observed $(103 \pm 77$ to $39 \pm 43 \mathrm{~ms}^{2} ; \mathrm{p}=0.003$ ) (Fig. 4). 
Table 1. Hemodynamic changes during and after GOS (graded orthostatic stress).

\begin{tabular}{|c|c|c|c|c|c|c|c|c|}
\hline & $\begin{array}{c}\text { HR } \\
{[\mathrm{bpm}]}\end{array}$ & $\begin{array}{c}\text { SI } \\
{\left[\mathbf{m l} / \mathbf{m}^{2}\right]}\end{array}$ & $\begin{array}{c}\text { CI } \\
{[\mathbf{l} /(\mathbf{m i n} *} \\
\left.\left.\mathbf{m}^{2}\right)\right]\end{array}$ & $\begin{array}{c}\text { TI } \\
{[\Omega]}\end{array}$ & $\begin{array}{c}\text { sBP } \\
{[\mathrm{mmHg}]}\end{array}$ & $\begin{array}{c}\text { dBP } \\
{[\mathrm{mmHg}]}\end{array}$ & $\begin{array}{c}\text { MAP } \\
{[\mathbf{m m H g ]}}\end{array}$ & $\begin{array}{c}\text { TPRI } \\
{\left[\text { dyne }^{*} \mathbf{s}^{*} \mathrm{~m}^{2} /\right.} \\
\left.\mathrm{cm}^{\wedge} 5\right]\end{array}$ \\
\hline$C 1$ & $75 \pm 15$ & $50 \pm 10$ & $3.7 \pm 0.7$ & $34.7 \pm 3.8$ & $137 \pm 17$ & $90 \pm 16$ & $106 \pm 16$ & $2306 \pm 496$ \\
\hline G1 & $91 \pm 18 * *$ & $37 \pm 5 * * *$ & $3.4 \pm 0.5$ & $36.3 \pm 4.1 * * *$ & $136 \pm 21$ & $95 \pm 22$ & $109 \pm 20$ & $2573 \pm 586$ \\
\hline G2 & $93 \pm 14 * *$ & $34 \pm 4 * * *$ & $3.2 \pm 0.4 * * *$ & $36.7 \pm 4.2 * * *$ & $135 \pm 17$ & $95 \pm 12$ & $109 \pm 12$ & $2691 \pm 448 *$ \\
\hline G3 & $106 \pm 18 * * *$ & $31 \pm 4 * * *$ & $3.3 \pm 0.4^{*}$ & $37.8 \pm 4.4 * * *$ & $129 \pm 20$ & $95 \pm 22$ & $106 \pm 20$ & $2543 \pm 642$ \\
\hline$P S$ & $128 \pm 26^{* * *}$ & $26 \pm 4 * * *$ & $3.2 \pm 0.3 * *$ & $38.9 \pm 4.6^{* * *}$ & $101 \pm 18 * * *$ & $75 \pm 14^{*}$ & $83 \pm 14 * * *$ & $1913 \pm 321 *$ \\
\hline$P G 1$ & $87 \pm 20$ & $46 \pm 8$ & $3.8 \pm 0.7$ & $36.2 \pm 4.2 * * *$ & $121 \pm 21$ & $76 \pm 15$ & $91 \pm 14^{*}$ & $1966 \pm 289 *$ \\
\hline$P G 2$ & $65 \pm 10$ & $53 \pm 10$ & $3.4 \pm 0.7$ & $35.4 \pm 4.2 *$ & $123 \pm 38$ & $79 \pm 26$ & $94 \pm 30$ & $2375 \pm 554$ \\
\hline
\end{tabular}

Heart rate (HR), stroke index (SI), cardiac index (CI), thoracic impedance (TI), systolic blood pressure (sBP), diastolic blood pressure (dBP), mean arterial blood pressure (MAP), total peripheral resistance index (TPRI). Values are mean \pm S.D. C1: supine control; G1: early tilt; G2: late tilt; G3: late GOS; PS: presyncope; PG1: early recovery; PG2: late control.***, P<0.0005; $* *, P<0.005 ;{ }^{*}, \mathrm{P}<0.05$.
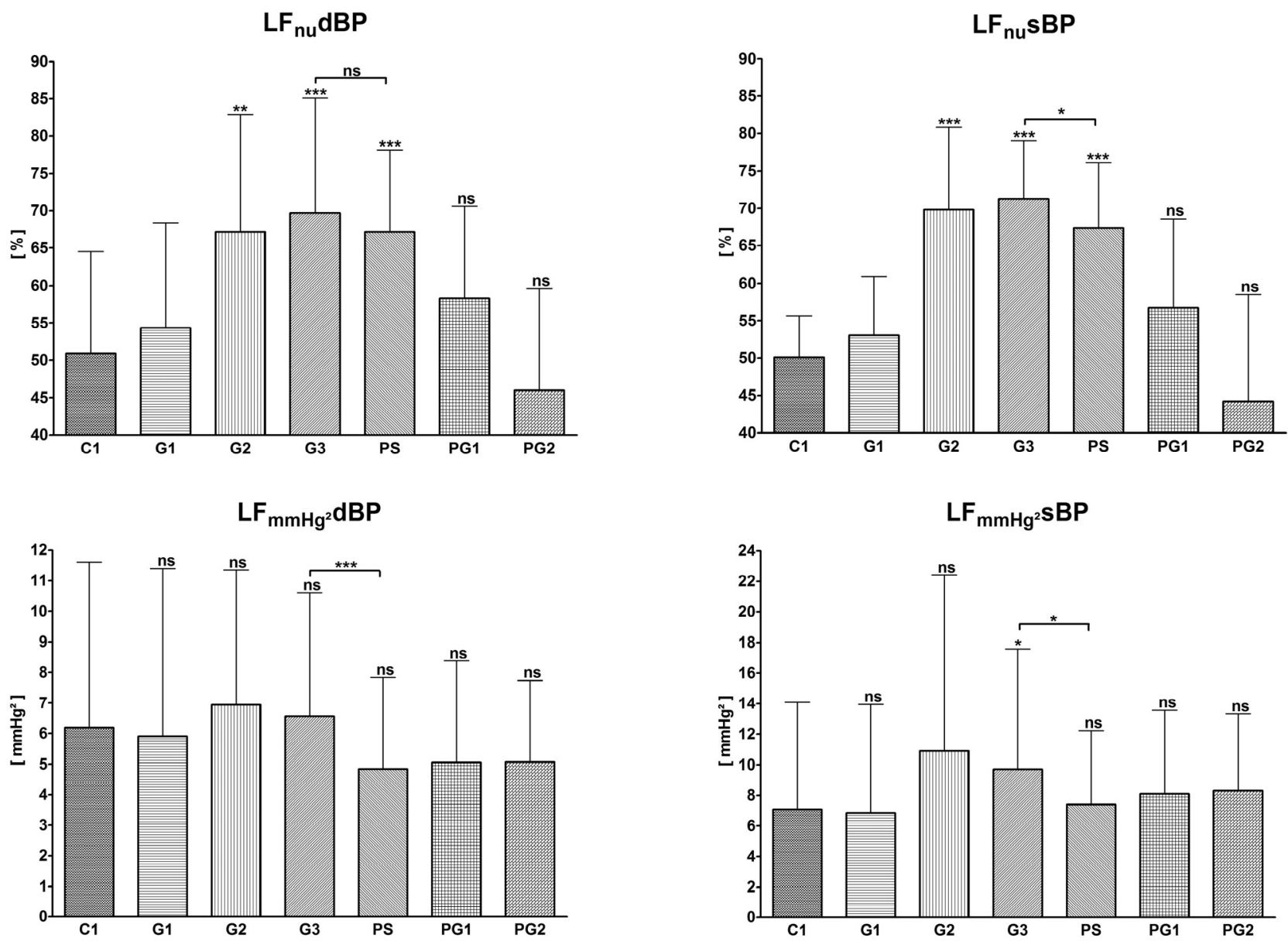

Fig. 3. Autonomic changes during and after $G O S$. $L F_{n u} d B P$ : low frequency of diastolic blood pressure, normalized values. $L F_{n u} S B P$ : low frequency of systolic blood pressure, normalized values. $\mathrm{LF}_{\mathrm{mmHg}} \mathrm{dBP}$ : low frequency of diastolic blood pressure, absolute values. $\mathrm{LF}_{\mathrm{mmH} \mathrm{g}_{2} \mathrm{SBP}} \mathrm{B}$ : low frequency of systolic blood pressure, absolute values. Bars show means $\pm \mathrm{S} . \mathrm{D}$. $* * *, \mathrm{P}<0.0005 ; * *, \mathrm{P}<0.005$; $*, \mathrm{P}<0.05$. 

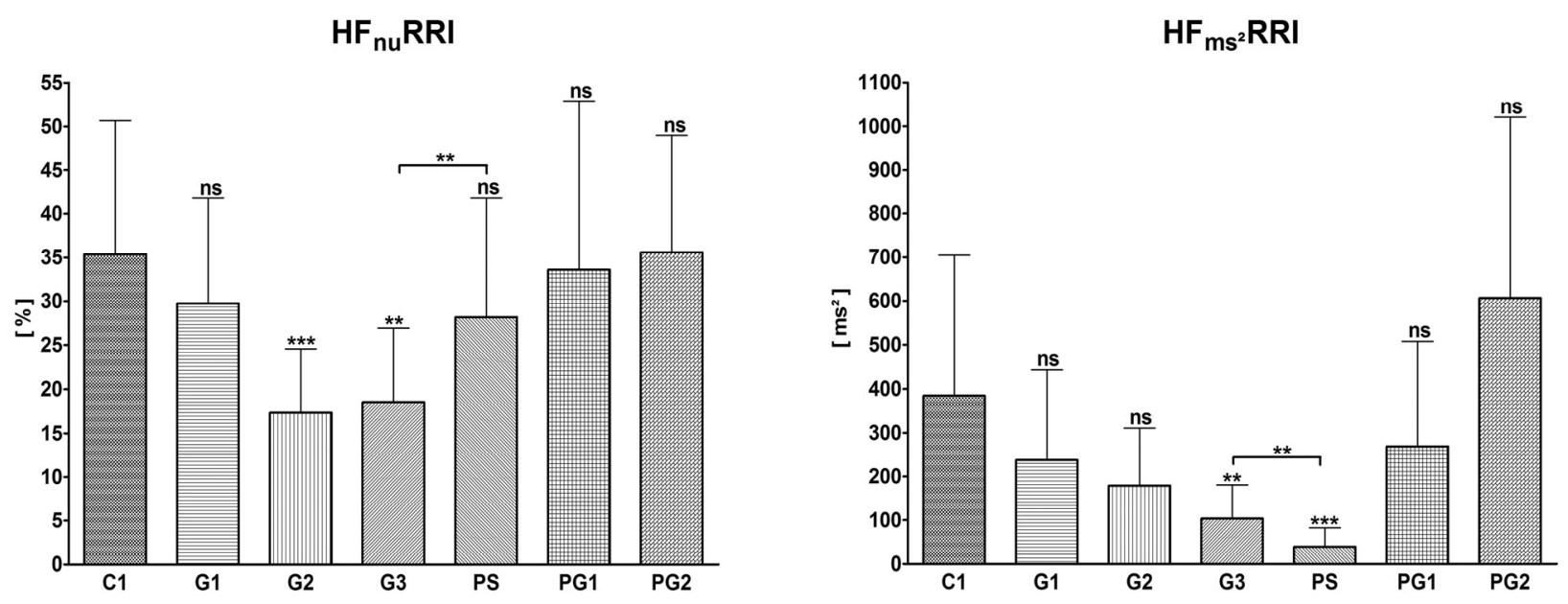

Fig. 4. Autonomic changes during and after GOS. $H F_{n u} R R I$ : high frequency variation of RR-interval, normalized values. $H F_{m s^{2}} R R I$ : high frequency variation of RR-interval, absolute values. C1: supine control; G1: early tilt; G2: late tilt; G3: late GOS; PS: presyncope; PG1: early recovery; PG2: late control. Bars show means \pm S.D. ***, $\mathrm{P}<0.0005 ; * *, \mathrm{P}<0.005 ; *, \mathrm{P}<0.05$.

\section{Discussion}

We present the evidence of reduced myocardial contractility, decreased total peripheral resistance and diminished sympathetic activity in healthy men undergoing orthostatically induced presyncope.

Several clinical studies have investigated myocardial contractility and changes in autonomic variables. Mizumaki et al. (1995) used echocardiography to assess the contractility status and power spectral analysis for HRV measurements. Mangin et al. (2003) employed peak endocardial acceleration (PEA) as an index of myocardial contractility and measured HRV through power spectral analysis. However, some investigators did not incorporate autonomic variables in their myocardial contractility studies but used impedance cardiography to assess myocardial contractility (Mitro and Hijová 2006). In the present investigation, we focused on changes in hemodynamic and myocardial contractility combined with autonomic activity using graded orthostatic stress (GOS) to provoke presyncope in non-medicated healthy male test subjects. We have previously used the combined head up tilt and graded lower body suction to study hemodynamic and neurohormonal responses to extreme orthostatic stress (Grasser et al. 2009), effect of Chinese herbs on cardiovascular responses (Gao et al. 2008) and more recently, to demonstrate post-reactive hyperemia in the human liver (Hinghofer-Szalkay et al. 2008).

\section{Hemodynamic changes}

With increasing orthostatic stress there was a steady increase in thoracic impedance from supine control to presyncope, suggesting increasing central hypovolemia (Pomerantz et al. 1970, Cai et al. 2000). Neurally mediated syncope is usually triggered by peripheral blood pooling, low venous return, and a "partially emptied" heart (Zaqqa and Massumi 2000); increased parasympathetic activity finally reduces heart rate, rendering cardiac output insufficient to support proper brain perfusion (Lurie and Benditt 1996). Brown and Hainsworth (2000) observed total peripheral resistance to fall from a level elevated $40 \%$ above supine values two minutes before, to $20 \%$ one minute before presyncope, indicating build-up of peripheral loss of vascular tone. We found total peripheral resistance index already decreased below supine control values one minute before presyncopal signs occurred.

Differences are conceivably dependent on the protocol used. Brown et al. (2000) used $20 \mathrm{mmHg}$ steps every $10 \mathrm{~min}$; we increased LBNP intensity by 3-min steps. We used impedance cardiography to calculate total peripheral resistance index from the baseline, while Brown et al. (2000) used brachial artery ultrasonography to indirectly assess cardiac output. We found a marked drop in resistance index from the last minute of tolerated LBNP to presyncope, indicating sympathetic withdrawal shortly before presyncope. It is possible that the elevated circulating norepinephrine (NE) and epinephrine (E) contributed to a beta-adrenergic receptor ( $\beta \mathrm{AR}$ ) downregulation in humans (Bristow et al. 1982). When receptors in intact cells or tissues are exposed to agonists, there is often a rapid decline in responsiveness. This process is called receptor desensitization (Pippig et al. 
1993). The time frames over which these processes occur range from seconds (phosphorylation) to minutes (endocytosis) and hours (down-regulation). In terms of $\beta_{2}$-AR the extent of receptor desensitization leads to attenuation of agonist potency and maximal responsiveness (Pippig et al. 1993, Fergusson 2001). The same might hold for $\alpha_{1}$-AR subtypes, which are the prime mediator of smooth muscle contraction (Piascik and Perez 2001). Experiments with knockout mice suggest that $\alpha_{1 \mathrm{~A}} \mathrm{AR}$ is the dominant adrenoreceptor for vascular smooth muscle contraction (Piascik and Perez 2001). Rudner et al. (1999) hypothesized that $\alpha_{1 \mathrm{~A}}-\mathrm{AR}$ mediated contraction may account for generalized splanchnic vasoconstriction during stress in humans. It is conceivable that elevated $\mathrm{NE}$ and $\mathrm{E}$ levels (both were observed to be elevated at presyncope compared to baseline, data not shown) led to a desensitization of adrenergic receptors, which would explain our observation of decreased myocardial contractility indices and peripheral resistance preceding syncope.

Another possible explanation could be metabolically driven vasodilation, which was found after strenuous exercise (Clifford and Hellsten 2004). Convertino and Sather (2000) have proposed that under orthostatic stress, beta adrenergic-induced tachycardia is a primary mechanism for the maintenance of arterial blood pressure. Our observed drop of total peripheral index decreased the mean arterial pressure in the last $60 \mathrm{~s}$ before presyncope. This is in agreement to previous findings (El-Bedawi and Hainworth 1994, Julu et al. 2003, Lelorier et al. 2003) that arterial pressure was no longer stabilized in this situation.

After the combined head-up tilt and LBNP, the heart rate, stroke index and cardiac index returned to supine control values within one minute, whereas blood pressure was still reduced. This could be attributed to the still below supine control levels of peripheral resistance at this point. Thoracic impedance stayed elevated above baseline for $15 \mathrm{~min}$ (PG2), probably due to fluid loss during GOS (Evans et al. 2004). However, cardiac output was not different from supine control.

\section{Myocardial contractility indicators changes}

Sudden reductions in venous return as caused by orthostatic stress primarily involve chronotropic instead of inotropic compensation (Guazzi et al. 1995). Indeed, all contractility indices decreased with presyncope in our study; index of contractility decreased progressively with increasing orthostatic load. Similarly, acceleration index and left ventricular working index were also decreased significantly at presyncope. Overall, the observations on cardiac contractility with (pre)syncope are controversial. Shalev et al. (1991) found powerful myocardial activity using echocardiography, but others observed no difference in myocardial contractility (Bellard et al. 2003) or even decreased contractility (Liu et al. 2000), also by using echocardiography. Using impedance cardiography, Mitro and Hijová (2006) also provided evidence against increased contractility. Mangin et al. (2001), using peak endocardial acceleration as index of myocardial contractility, found that cardiac inotropy increased gradually during the entire testing in a head-up tilt positive subgroup, but they also observed a decrease in myocardial contractility during fainting.

Following $60 \mathrm{~s}$ of stress cessation, the index of contractility and left ventricular working index were not different from baseline levels. However, acceleration index, was increased $60 \mathrm{~s}$ following the termination of graded orthostatic stress. A recent study, which also used impedance cardiography, observed a trend towards increased myocardial contractility one minute after syncope (Mitro et al. 2006). These authors speculated that the increased inotropy might represent a compensatory mechanism originating from a sympathetic reflex response to increased peripheral blood pooling.

\section{Heart rate and blood pressure variability}

Vasovagal syncope is associated with a sudden onset of hypotension, often in combination with bradycardia or transient asystole, probably due to sympathetic withdrawal. Shortly before presyncope, we observed low frequency power components of diastolic and systolic blood pressure increased, whereas absolute values showed no change compared to baseline. As total power variance is reduced, the absolute power of low frequency appears to be unchanged compared to the rest (Camm et al. 1996). Low frequency power components of diastolic and systolic blood pressure both decreased between late graded stress and presyncope, indicating sudden sympathetic withdrawal which is in agreement with previous findings and matches the decrease in vascular resistance index, acceleration index and left ventricular working index. The high frequency power component of RR-interval $\left(\mathrm{HF}_{\mathrm{ms}^{2}} \mathrm{RRI}\right)$ was below baseline levels at presyncope, while $H_{\text {nu }} R R I$ remained unchanged. Using power spectral analysis of heart rate variability, Mizumaki et al. (1995) also found decreased presyncopal high frequency power component of RR- 
interval in their control group of healthy men. Similarly, Mangin et al. (2001) found a marked presyncopal drop in the high frequency power component of RR-interval in subjects prone to syncope. However, they used isoproterenol infusion to provoke syncope in their test subjects and this could influence the autonomic system. We observed $\mathrm{HF}_{\mathrm{nu}} \mathrm{RRI}$ decreased at end of tilt phase and at late graded orthostatic stress compared to controls, which suggests low parasympathetic activity. From late graded stress to presyncope, however, $H_{n u} R R I$ increased, indicating vagal activation shortly before presyncopal signs or symptoms occurred. This is in agreement with previous observations (Furlan et al. 1998, Kamiya et al. 2005). Piccirillo et al. (2004) found diminished $\mathrm{HF}_{\mathrm{nu}} \mathrm{RRI}$ in the early stage of head-up tilt but no change from their first recording to their second, denoted as the last 256 beats before syncope. This discrepancy to our observation could be attributed to the breathing patterns, as our subjects were allowed to breathe freely. Higher breathing frequency in the presyncopal state elevates the $\mathrm{HF}_{\mathrm{nu}} \mathrm{RRI}$ (Piccirillo et al. 2004).

\section{Limitations}

We studied healthy males with no history of syncope. We cannot generalize our findings to patients with vasovagal syncope or orthostatic intolerance. To simulate real life scenario characterized by spontaneous ventilatory activity, we did not control breathing, as this is known to influence heart rate and blood pressure variability (Piccirillo et al. 2004).

\section{Conclusions}

Myocardial contractility indices and parameters of sympathetic activity were reduced in the presyncopal state, while indication of parasympathic activity was increased. This suggests a decrease in cardiac contractility during orthostatically induced presyncope in healthy young subjects. Additional investigations are warranted to confirm these findings across a larger age range, in both men and women and in non-healthy subjects.

\section{Conflict of Interest}

There is no conflict of interest.

\section{Acknowledgements}

We wish to thank MD Max Jordis for his medical support, Prof. Andreas Rössler and Ing. Andreas Jantscher for their outstanding technical support and the Austromars crew for their excellent compliance. The simulation and part of the LBNP-tests were financed under a grant from the Austrian Space Applications Program of the Federal Ministry for Transportation, Innovation and Technology.

\section{References}

BELLARD E, FORTRAT JO, SCHANG D, DUPUIS JM, VICTOR J, LEFTHERIOTIS G: Changes in the transthoracic impedance signal predict the outcome of a 70 degrees head-up tilt test. Clin Sci 104: 119-126, 2003.

BRISTOW MR, GINSBURG R, MINOBE W, CUBICCIOTTI RS, SAGEMAN WS, LURIE K, BILLINGHAM ME, HARRISON DC, STINSON EB: Decreased catecholamine sensitivity and beta-adrenergic-receptor density in failing human hearts. N Engl J Med 307: 205-211, 1982.

BROWN CM, HAINSWORTH R: Forearm vascular responses during orthostatic stress in control subjects and patients with posturally related syncope. Clin Auton Res 10: 57-61, 2000.

CAI Y, HOLM S, JENSTRUP M, STROMSTAD M, EIGTVED A, WARBERG J, HOJGAARD L, FRIBERG L, SECHER NH: Electrical admittance for filling of the heart during lower body negative pressure in humans. J Appl Physiol 89: 1569-1576, 2000.

CAMM AJ, MALIK M, BIGGER JT, BREITHARDT G, CERUTTI S, COHEN RJ, COUMEL P, FALLEN EL, KENNEDY HL, KLEIGER RE, LOMBARDI F, MALLIANI A, MOSS AJ, ROTTMAN JN, SCHMIDT G, SCHWARTZ PJ, SINGER DH: Heart rate variability. Standards of measurement, physiological interpretation, and clinical use. Eur Heart J 17: 354-381, 1996.

CLIFFORD PS, HELLSTEN Y: Vasodilatory mechanisms in contracting skeletal muscle. J Appl Physiol 97: 393-403, 2004. 
CONVERTINO VA, SATHER TM: Effects of cholinergic and beta-adrenergic blockade on orthostatic tolerance in healthy subjects. Clin Auton Res 10: 327-336, 2000.

EL-BEDAWI KM, HAINSWORTH R: Combined head-up tilt and lower body suction: A test of orthostatic tolerance. Clin Auton Res 4: 41-47, 1994.

EVANS JM, STENGER MB, MOORE FB, HINGHOFER-SZALKAY H, ROSSLER A, PATWARDHAN AR, BROWN DR, ZIEGLER MG, KNAPP CF: Centrifuge training increases presyncopal orthostatic tolerance in ambulatory men. Aviat Space Environ Med 75: 850-858, 2004.

FERGUSON SSG: Evolving concepts in G protein-coupled receptor endocytosis: the role in receptor desensitization and signaling. Pharmacol Rev 53: 1-24, 2001.

FORTIN J, HABENBACHER W, HELLER A, HACKER A, GRULLENBERGER R, INNERHOFER J, PASSATH H, WAGNER C, HAITCHI G, FLOTZINGER D: Non-invasive beat-to-beat cardiac output monitoring by an improved method of transthoracic bioimpedance measurement. Comput Biol Med 36: 1185-1203, 2006.

FURLAN R, PIAZZA S, DELL'ORTO S, BARBIC F, BIANCHI A, MAINARDI L, CERUTTI S, PAGANI M, MALLIANI A: Cardiac autonomic patterns preceding occasional vasovagal reactions in healthy humans. Circulation 98: 1756-1761, 1998.

GAO Y, GOSWAMI N, GRASSER E, ROESSLER A, STOEGER E, SCHWABERGER G, HINGHOFERSZALKAY H: Radix Astragali and orthostatic response: a double masked crossover study. Aviat Space Environ Med 79: 94-98, 2008.

GOSWAMI N, LOEPPKY J, HINGHOFER-SZALKAY H: LBNP: Past protocols and technical considerations for experimental design. Aviat Space Environ Med 79: 1-13, 2008.

GOSWAMI N, GRASSER E, ROESSLER A, SCHNEDITZ D, HINGHOFER-SZALKAY H: The cardiovascular response to lower body negative pressure in humans depends on seal location Physiol Res 58: 311-318, 2009.

GRASSER EK, GOSWAMI N, RÖSSLER A, VRECKO K, HINGHOFER-SZALKAY H: Hemodynamic and neurohormonal responses to extreme orthostatic stress in physically fit young adults. Acta Astronautica 64: 688-696, 2009.

GUAZZI M, PEPI M, MALTAGLIATI A, CELESTE F, MURATORI M, TAMBORINI G: How the two sides of the heart adapt to graded impedance to venous return with head-up tilting. J Am Coll Cardiol 26: 1732-1740, 1995.

HINGHOFER-SZALKAY HG, ROESSLER A, EVANS JM, STENGER MB, MOORE FB, KNAPP CF: Circulatory galanin levels increase several fold with intense orthostatic challenge in healthy humans $J$ Appl Physiol 100: 844-849, 2006.

HINGHOFER-SZALKAY H, GOSWAMI N, ROESSLER A, GRASSER E, SCHNEDITZ D: Reactive hyperemia in the human liver. Am J Physiol 295: G332-G337, 2008.

JULU POO, COOPER VL, HANSEN S, HAINSWORTH R: Cardiovascular regulation in the period preceding vasovagal syncope in conscious humans. J Physiol 549: 299-311, 2003.

KAMIYA A, HAYANO J, KAWADA T, MICHIKAMI D, YAMAMOTO K, ARIUMI H, SHIMIZU S, UEMURA K, MIYAMOTO T, AIBA T, SUNAGAWA K, SUGIMACHI M: Low-frequency oscillation of sympathetic nerve activity decreases during development of tilt-induced syncope preceding sympathetic withdrawal and bradycardia. Am J Physiol 289: H1758-H1769, 2005.

KAPOOR WN: Primary care - syncope. N Engl J Med 343: 1856-1862, 2000.

LELORIER P, KLEIN G, KRAHN A, RAYMOND Y, SKANES AC, SHOEMAKER KJ: Combined head-up tilt and lower body negative pressure as an experimental model of orthostatic syncope. J Cardiovasc Electrophysiol 14: 920-924, 2003.

LIU JE, HAHN RT, STEIN KM, MARKOWITZ SM, OKIN PM, DEVEREUX RB, AND LERMAN BB: Left ventricular geometry and function preceding neurally mediated syncope. Circulation 101: 777-783, 2000.

LURIE KG, BENDITT D: Syncope and the autonomic nervous system. J Cardiovasc Electrophysiol 7: 760-776, 1996.

MALLIANI A, PAGANI M, LOMBARDI F, CERUTTI S: Cardiovascular neural regulation explored in the frequency domain. Circulation 84: 482-492, 1991.

MANGIN L, KOBEISSI A, LELOUCHE D, D'HEROUVILLE Y, MANSIER P, SWYNGHEDAUW B, MACQUINMAVIER I: Simultaneous analysis of heart rate variability and myocardial contractility during head-up tilt in patients with vasovagal syncope. J Cardiovasc Electrophysiol 12: 639-644, 2001. 
MITRO P, HIJOVÁ E: Myocardial contractility and cardiac filling measured by impedance cardiography in patients with nitroglycerine-induced vasovagal syncope. Pacing Clin Electrophysiol 29: 1-8, 2006.

MIZUMAKI K, FUJIKI A, TANI M, SHIMONO M, HAYASHI H, INOUE H: Left-ventricular dimensions and autonomic balance during head-up tilt differ between patients with isoproterenol-dependent and isoproterenolindependent neurally mediated syncope. J Am Coll Cardiol 26: 164-173, 1995.

MORILLO CA, KLEIN GJ, JONES DL, YEE R: Time and frequency-domain analyses of heart-rate-variability during orthostatic stress in patients with neurally-mediated syncope. Am J Cardiol 74: 1258-1262, 1994.

MOSQUEDA-GARCIA R, FURLAN R, FERNANDEZ-VIOLANTE RD, TUSHAR SM, JARAI Z, ANANTHRAM V, ROBERTSON RM, ROBERTSON D: Sympathetic and baroreceptor reflex function in neurally mediated syncope evoked by tilt. J Clin Invest 99: 2736-2744, 1997.

OBERG B, THOREN P: Increased activity in left ventricular receptors during hemorrhage or occlusion of caval veins in cat: A possible cause of vaso-vagal reaction. Acta Physiol Scand 85: 164-173, 1972.

PAGANI M, MONTANO N, PORTA A, MALLIANI A, ABBOUD FM, BIRKETT C, SOMERS VK: Relationship between spectral components of cardiovascular variabilities and direct measures of muscle sympathetic nerve activity in humans. Circulation 95: 1441-1448, 1997.

PIASCIK MT, PEREZ DM: Alpha 1 -adrenergic receptors: new insights and directions. J Pharmacol Exp Ther 298: 403410, 2001.

PICCIRILlO G, NASO C, MOISE A, LIONETTI M, NOCCO M, Di CARLO S, DE LAURENTIS T, MAGRI D, CACCIAFESTA M, MARIGLIANO V: Heart rate and blood pressure variability in subjects with vasovagal syncope. Clin Sci 107: 55-61, 2004.

PIPPIG S, ANDEXINGER S, DANIEL K, PUZICHA M, CARON MG, LEFKOWITZ RJ, LOHSE MJ: Over expression of beta-arrestin and beta-adrenergic receptor kinase augment desensitization of $\beta_{2}$-adrenergic receptors. J Biol Chem 268: 3201-3208, 1993.

POMERANTZ M, DELGADO F, EISEMAN B: Clinical evaluation of transthoracic electrical impedance as a guide to intrathoracic fluid volumes. Ann Surg 171: 686-694, 1970.

RUDNER XL, BERKOWITZ DE, BOOTH JV, FUNK BL, COZART KL, D'AMICO EB, EL-MOALEM H, PAGE SO, RICHARDSON CD, WINTERS B, MARUCCI L, SCHWINN DA: Subtype specific regulation of human vascular alpha ${ }_{1}$-adrenergic receptors by vessel bed and age. Circulation 100: 2336-2343, 1999.

SHALEV Y, GAL R, TCHOU PJ, ANDERSON AJ, AVITALL B, AKHTAR M, JAZAYERI MR: Echocardiographic demonstration of decreased left ventricular dimensions and vigorous myocardial contraction during syncope induced by head-up tilt. J Am Coll Cardiol 18: 746-751, 1991.

STAUSS HM: Heart rate variability. Am J Physiol 285: R927-R931, 2003.

WESSELING KH: Finger arterial pressure measurement with Finapres. Z Kardiol 85: 38-44, 1996.

ZAQQA M, MASSUMI A: Neurally mediated syncope. Tex Heart Inst J 27: 268-272, 2000. 